\title{
Development of Acute Pancreatitis Due to Pegylated Interferon Alpha 2a in a Patient with Chronic Hepatitis B: A Case Report
}

\author{
Kronik Hepatit B'li Bir Hastada Pegile Interferon Alfa 2a Tedavisine Bağlı Akut Pankreatit \\ Gelișimi: Olgu Sunumu
}

\author{
Şükran KÖSE1, Melda TÜRKEN1, Mehmet TANRISEV2, Gülgün AKKOÇLU1 \\ ${ }^{1}$ Tepecik Training and Research Hospital, Clinic of Infectious Diseases, Izmir, Turkey \\ 2Tepecik Training and Research Hospital, Clinic of Internal Medicine Nephrology, Izmir, Turkey
}

\begin{abstract}
Interferons (IFNs) are immunomodulatory and antiviral agents used in the treatment of chronic hepatitis B and C. Development of acute pancreatitis is a very rare complication seen during IFN (pegylated or standard) treatment in chronic viral hepatitis. In this report, we present a 50-year-old patient with chronic renal insufficiency and chronic hepatitis B who developed acute pancreatitis during treatment with peg-IFN alpha-2a.

Key Words: Chronic hepatitis B, pegylated interferon alpha 2a, acute pancreatitis
\end{abstract}

Conflict of interest: The authors reported no conflict of interest related to this article.

\section{ÖZET}

Interferonlar (IFNs) kronik viral hepatit B ve C tedavisinde kullanilan, immünmodülatör ve antiviral etkinliği olan ajanlardır. Kronik viral hepatitlerde IFN (pegile veya standart) tedavisi sırasında akut pankreatit gelişmesi çok nadir bir komplikasyondur. Bu raporda kronik hepatit B ve kronik böbrek yetmezlikli, peg-IFN alfa-2a tedavisi ile akut pankreatit gelişen, 50 yaşında bir hastayı sunduk.

Anahtar Kelimeler: Kronik hepatit B, pegile interferon alfa, akut pankreatit

Çıkar çatışması: Yazarlar bu makale ile ilgili olarak herhangi bir çıkar çatışması bildirmemişlerdir.

\section{Introduction}

Interferons (IFNs) are immunomodulatory and antiviral agents used in the treatment of chronic hepatitis $\mathrm{B}(\mathrm{CHB})$ and chronic hepatitis $\mathrm{C}(\mathrm{CHC})$. The main side effects of IFNs include flulike symptoms, hematological abnormalities and gastrointestinal, neuropsychiatric, dermatological and respiratory symptoms. Development of acute pancreatitis is a very rare complication seen during IFN (pegylated or standard) treatment of chronic viral hepatitis $(1,2)$. In the literature, when concurrent cases with HIV infection are excluded, development of acute pancreatitis is reported in 49 cases due to standard IFN alpha and 5 cases due to peg-IFN alpha-2b plus ribavirin treatment in $\mathrm{CHC}$ patients $(3,4,5,6,7)$. On the other hand, there is only one reported case of acute pancreatitis occurring during IFN treatment of $\mathrm{CHB}$ (8). In this report, we present a patient with chronic renal insufficiency (CRI) and $\mathrm{CHB}$ who developed acute pancreatitis during treatment with peg-IFN alpha-2a.

\section{Case}

A 50-year-old male patient has been on hemodialysis for seven years due to $\mathrm{CRI}$ and was being followed up for $\mathrm{CHB}$ for six years. The patient is candidate for renal transplant.

The patient was using salbutamol inhaler for chronic bronchitis and phos-ex (phosphor chelating agent) for CRI, hemodialysis was applied three times a week and he did neither smoke nor used alcohol. During follow-up, when findings of positive $\mathrm{HBsAg}$, negative $\mathrm{HBeAg}$, positive anti HBe, HBV DNA 9.6×104 copies/mL (PCR), liver biopsy Knodel activity index of 11, fibrosis of 1 were detected, pegylated IFN treatment was planned.

Physical examination before IFN treatment revealed no special characteristics, apart from diffuse bilateral expiratory rhonchi. Findings of laboratory investigations were as follows: WBC: 6900/ mm33 $\mathrm{Hb}: 13.4 \mathrm{~g} / \mathrm{dL}, \mathrm{Hct}: 41.6 \%$, Plt: 139.000/mm³, erythrocyte sedimentation rate: $12 \mathrm{~mm} / \mathrm{h}$, glu: $98 \mathrm{mg} / \mathrm{dL}$, urea: $107 \mathrm{mg} / \mathrm{dL}$ 
creat: $6.6 \mathrm{mg} / \mathrm{dL}$, AST: $8 \mathrm{U} / \mathrm{L}, \mathrm{ALT}: 11 \mathrm{U} / \mathrm{L}, \mathrm{GGT}: 17 \mathrm{U} / \mathrm{L}, \mathrm{LDH}: 152$ U/L, CK: 47 U/L, Amilase: 29 U/L, T.bil: 0.4 mg/dL, D.bil $0.1 \mathrm{mg} / \mathrm{dL}$ Alb: 4g/dL, Glob: $3 \mathrm{~g} / \mathrm{dL}, \mathrm{TG}: 95 \mathrm{mg} / \mathrm{dL}$, Cholesterol: $148 \mathrm{mg} / \mathrm{dL}$, Ca: $9.3 \mathrm{mg} / \mathrm{dL}, \mathrm{P}: 4.3 \mathrm{mg} / \mathrm{dL}, \mathrm{Na}: 137 \mathrm{mmo} / \mathrm{L}, \mathrm{K}: 4.6 \mathrm{mmo} / \mathrm{L}, \mathrm{Cl}$ : $98 \mathrm{mmol} / \mathrm{L}$, negative autoantibodies and normal thyroid functions. Chest tomography revealed increased aerization compatible with amphysema. During consultation with the pulmonary diseases clinic, continuation of the current bronchodilatator treatment was recommended. No pathological finding was detected in fundus evaluation, odiometric measurement and psychiatric evaluation.

CHB treatment with peg-IFN alpha $2 a 135 \mathrm{mcg} / \mathrm{wk}$ was initiated. During the $5^{\text {th }}$ week of treatment, the patient was hospitalized due to abdominal pain, nausea and vomiting. Findings of laboratory evaluations were as follows: WBC: $9000 / \mathrm{mm}^{3}$, Hb: 12.2 g/dL, Hct: \%32.8, Plt: 152.000/mm33, Glu: 114 mg/dL, Urea: 79 mg/dL, Creat: 4.9 mg/dL, AST: 176 U/L, ALT: 64 U/L, CK: 1884U/L, Amilase: 1529 U/L, TG: 102 mg/dL, Cholesterol: 144 mg/ dL, Ca: $9 \mathrm{mg} / \mathrm{dL}$, P: $4.3 \mathrm{mg} / \mathrm{dL}, \mathrm{Na:} 133 \mathrm{mmol} / \mathrm{L}, \mathrm{K}: 4.1 \mathrm{mmol} / \mathrm{L}$, $\mathrm{Cl}: 97 \mathrm{mmol} / \mathrm{L}$. Abdominal USG and MR cholangiography showed dilatation of the intrahepatic bile ducts and mild dilatation in the extrahepatic bile ducts. No pathology leading to obstruction was detected. Upper abdominal MR showed hydropic gallbladder, mild peripancreatic oedema and diffuse ascites in the abdomen. Based on these clinical and laboratory findings, the patient was diagnosed as having acute pancreatitis.

After other causes of acute pancreatitis were excluded, it was concluded that the case was due to IFN treatment, and accordingly, peg-IFN alfa 2a treatment was suspended. Supportive therapy was applied. The patient was discharged after 10 days upon improvement of clinical and laboratory findings. During follow-up of the patient, peg-IFN treatment was not resumed. During six-month follow-up, no recurrence of symptoms was seen.

\section{Discussion}

In $90 \%$ of acute pancreatitis cases, the etiological cause is alcohol or biliary system diseases. Other causes, such as hyperlipidemia, hypercalcemia, trauma, ischemia, pancreatic duct/ duodenum obstruction, viral infections, snake venom and drugs are rarely seen. In about $10 \%$ of the cases, the cause is not known (9).

In our case, the patient presented with metabolic changes due to CRI. Nevertheless, acute pancreatitis developed after pegIFN therapy was initiated for $\mathrm{CHB}$, and following the cessation of treatment, the clinical and laboratory findings improved.

IFN alpha is a rare cause of drug-induced pancreatitis. The reported cases in the literature are acute pancreatitis cases developed in patients using IFN alpha or peg-IFN alpha-2b for $\mathrm{CHC}(1,3,4,5,6,7,10,11,12)$. On the other hand, one case of acute pancreatitis induced by peg-IFN in CHB has also been reported (8).

IFN alpha may induce acute pancreatitis through several mechanisms. IFN alpha therapy may cause hypertriglyceridemia and this may lead to acute pancreatitis, but this theory does not explain the development of acute pancreatitis in our patient, because the triglyceride level in our patient was normal. IFN alpha may also cause autoimmune destruction in the pancreas by stimulating the immune system and hence, induce acute pancreatitis $(13,14,15)$. It is well known that IFN alpha triggers certain autoimmune diseases like diabetes and thyroid disease (1). Other case reports in the literature have also focused on this theory. High TNF- $\alpha$ and IL-6 have been described as inducing and mediating acute pancreatitis, and as having immunomodulatory cytokines.

Drug-induced acute pancreatitis is diagnosed on the basis of the presence of symptoms, such as epigastric pain, nausea and vomiting, appetite loss, elevated amylase and lipase levels, and the absence of other identifiable causes of pancreatitis (16). These findings met the criteria for probable drug-induced pancreatitis. The onset of pancreatitis during PEG-IFN treatment and the resolution of the symptoms after discontinuing the treatment confirmed the diagnosis.

As a result, IFNs used in the treatment of chronic viral hepatitis may cause development of acute pancreatitis, even though it is rarely observed. Presenting this specific case, we aimed to emphasize that acute pancreatitis may develop during IFN treatment and this fact should be taken into consideration during clinical and laboratory evaluations.

\section{References}

1. Chaudhari S, Park J, Anand BS, Pimstone NR, Dieterich DT, Batash $S$, et al. Acute pancreatitis associated with interferon and ribavirin therapy in patients with chronic hepatitis C. Dig Dis Sci.2004;49:1000-1006.

2. Russo MW, Fried MW. Side effects of therapy for chronic hepatitis C. Gastroenterology 2003;124:1711-1719.

3. Tahan V, Tahan G, Dane F, Uraz S, Yardim M. Acute pancreatitis attributed to the use of pegylated interferon in a patient with chronic hepatitis C. J Gastrointestin Liver Dis. 2007;16(2):224225.

4. Kabbaj N, Sentissi S, Guedira MM, Mohammadi M, Benaïssa A, Amrani N. Acute pancreatitis during treatment for chronic viral hepatitis C. Gastroenterol Clin Biol. 2008;32:232-233.

5. Kok KF, De Vries RA. Acute pancreatitis in a hepatitis $C$ positive patient following treatment with peginterferon alfa-2b and ribavirin. Ned Tijdschr Geneeskd. 2006;150:681-683.

6. Cecchi E, Forte P, Cini E, Banchelli G, Ferlito C, Mugelli A. Pancreatitis induced by pegylated interferon alfa-2b in a patient affected by chronic hepatitis C. Emerg Med Australas. 2004;16:473-475.

7. Ozdogan O, Tahan V, Cincin A, Imeryuz N, Tozun N. Acute pancreatitis associated to the use of peginterferon. Pancreas. 2007;34:485-487.

8. Vignon RK, Seddik H, Rouibaa F, En-Nouali H, Kabbaj N, Benkirane A. Benkirane Acute pancreatitis during pegylated interferon therapy in a patient with chronic hepatitis B. J Gastrointestin Liver Dis. 2009;18(4):512.

9. Steinberg W, Tenner S. Acute pancreatitis. N Engl J Med. 1994;330:1198-1210.

10. Eland IA, Rasch MC, Sturkenboom MJ, Bekkering FC, Brouwer JT, Delwaide J, Belaiche J, Houbiers G, Stricker BH. Acute pancreatitis attributed to the use of interferon alfa-2b. Gastroenterology. 2000;119:230-233.

11. Mallory A, Kern F Jr. Drug-induced pancreatitis: a critical review. Gastroenterology. 1980;78:813-820. 
12. Kim SR, Imoto S, Mita K, Taniguchi M, Sasase N, Muramatsu A, Kudo M, Kitai S, El-Shamy A, Hotta H, Hayashi Y. Pegylated interferon plus ribavirin combination therapy for chronic hepatitis $\mathrm{C}$ with high viral load of serum hepatitis $\mathrm{C}$ virus RNA, genotype $1 \mathrm{~b}$, discontinued on attaining sustained virological response at week 16 after onset of acute pancreatitis. Digestion. 2009;79(1):36-39.

13. Fernandez-Miranda C, Castellano G, Guijarro C, Fernandez I, Schoebel N, Larumbe S, Gómez-lzquierdo T, del Palacio A. Lipoprotein changes in patients with chronic hepatitis $C$ treated with interferon-alpha. Am J Gastroenterol. 1998;93:1901-1904.

14. Naeem M, Bacon BR, Mistry B, Britton RS, Di Bisceglie AM. Changes in serum lipoprotein profile during interferon therapy in chronic hepatitis C. Am J Gastroenterol. 2001;96:2468-2472.

15. Shinohara E, Yamashita S, Kihara S, Hirano K, Ishigami M, Arai T, Nozaki S, Kameda-Takemura K, Kawata S, Matsuzawa Y. Interferon alpha induces disorder of lipid metabolism by lowering postheparin lipases and cholesteryl ester transfer protein activities in patients with chronic hepatitis C. Hepatology. 1997;25:1502-1506.

16. Ando K, Kim SR, Imoto S, Nakajima T, Mita K, Fukuda K, Taniguchi M, Sasase N, Muramatsu A, Matsuoka T, Kudo M, Hayashi Y. Acute Pancreatitis Associated with Pegylated Interferon and Ribavirin Treatment of Chronic Hepatitis C, Genotype 1b with High Viral Load. Case Rep Gastroenterol. 2009;3(3):372-376. 